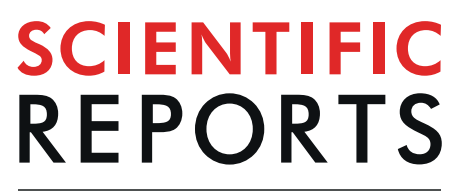

natureresearch

\title{
Near-Infrared Fluorescent pH Responsive Probe for Targeted Photodynamic Cancer Therapy
}

\author{
Siriwalee Siriwibool ${ }^{1,5}$, Nantawat Kaekratoke ${ }^{1,5}$, Kantapat Chansaenpak², \\ Kittipan Siwawannapong ${ }^{1}$, Pannipa Panajapo ${ }^{1}$, Kritsana Sagarik ${ }^{1}$, Parinya Noisa ${ }^{3,4}$, \\ Rung-Yi Lai ${ }^{1,4}$ \& Anyanee Kamkaew ${ }^{1,4^{*}}$
}

We developed a pH dependent amino heptamethine cyanine based theranostic probe ( $\mathrm{I}_{2}$-IR783-Mpip) that can be activated by near infrared light. $\mathrm{I}_{2}$-IR783-Mpip, in acidic condition, exhibited an intense, broad NIR absorption band $(820-950 \mathrm{~nm})$ with high singlet oxygen generation upon exposure to NIR light $(\sim 850 \mathrm{~nm})$. Theoretical calculations showed that the protonation of the probe in an acidic environment decreased the molecular orbital energy gaps and increased the intramolecular charge transfer efficiency. $\mathrm{I}_{2}$-IR783-Mpip exhibited good photodynamic efficiency towards liver hepatocellular carcinoma cells under physiological and slightly acidic conditions while normal human embryonic kidney cells remained alive under the same conditions. Detection of intracellular reactive oxygen species (ROS) in cells treated with $\mathrm{I}_{2}$-IR783-Mpip after NIR light exposure confirmed PDT efficiency of the probe in acidic environment. Moreover, $\mathrm{I}_{2}$-IR783-Mpip also demonstrated efficient phototoxicity under deep-seated tumour cell system. We believed this is the first PDT agent that possesses intrinsic tumour binding and selectively eradicate tumour in acidic environment under $850 \mathrm{~nm}$ NIR lamp.

Photodynamic therapy (PDT) is an attractive non-invasive technique for treating cancers. Extensively, two steps are involved in PDT including, (i) delivery of a photodynamic agent to tumours and (ii) irradiation of tumour sites with specific light to activate PDT agent followed by reactive oxygen species (ROS) generation that triggers cancer cell death ${ }^{1}$. In general, cancer cells behave differently by comparison with normal cells. For example, the lack of oxygen in tumour creates strong hypoxia condition leading to lactic acid build-up and lower extracellular $\mathrm{pH}$ level in tumour environment $(\mathrm{pH} \text { 6.2-6.9) })^{2,3}$. In addition, the lysosomal $\mathrm{pH}$ in cancer cells $\left(\mathrm{pH}_{\mathrm{lys}} 3.8-4.7\right)$ shows higher acidity than that in normal cells $\left(\mathrm{pH}_{\mathrm{lys}} 4.5-6.0\right)^{4}$.

Near-infrared fluorescent dyes that can absorb and emit light in a range $700-1000 \mathrm{~nm}$ are good for tumour detection at millimetre depth due to less background fluorescence from endogenous molecules ${ }^{5,6}$. Among them, heptamethine cyanines (Hcyanines) were used extensively as tools for cancer imaging because of their high fluorescence quantum yields, great photothermal and/or photodynamic effect and good biocompatibility ${ }^{7,8}$. Moreover, Hcyanines could be internalized by cancer cell through organic anion-transporting polypeptides (OATPs), a group of cell membrane-bound solute carriers ${ }^{9-11}$. OATPs could mediate the cellular transport of drug and exogenous materials ${ }^{12}$. The uptake of Hcyanines in cancer cells was concerted actions exerted by hypoxia and activation of HIF1alpha/OATPs signalling leading to enhance dye uptake, but little to no accumulation in normal cells due to low expression of OATPs ${ }^{13}$.

Recently, some nanomaterials based Hcyanines were reported to target acidic tumour environment with therapeutic effects ${ }^{14,15}$. However, only few Hcyanines have been reported as the stand-alone small molecules targeted cancer that were $\mathrm{pH}$ sensitive and generated heat after activation (so-called photothermal effect) or produced PDT effect. For example, IR2 was reported as a pH switchable NIR fluorescence and photothermal agent by adjusting the intramolecular charge transfer (ICT) efficiency using dimethylamine group. By this way, IR2 could

\footnotetext{
${ }^{1}$ School of Chemistry, Institute of Science, Suranaree University of Technology, Nakhon, Ratchasima, 30000, Thailand. ${ }^{2}$ National Nanotechnology Center, National Science and Technology Development Agency, Thailand Science Park, Pathum Thani, 12120, Thailand. ${ }^{3}$ Laboratory of Cell-Based Assays and Innovations, School of Biotechnology, Institute of Agricultural Technology, Suranaree University of Technology, Nakhon Ratchasima, 30000 , Thailand. ${ }^{4}$ Center of Excellence in Advanced Functional Materials, Suranaree University of Technology, Nakhon Ratchasima, 30000, Thailand. ${ }^{5}$ These authors contributed equally: Siriwalee Siriwibool and Nantawat Kaekratoke. *email: anyanee@sut.ac.th
} 

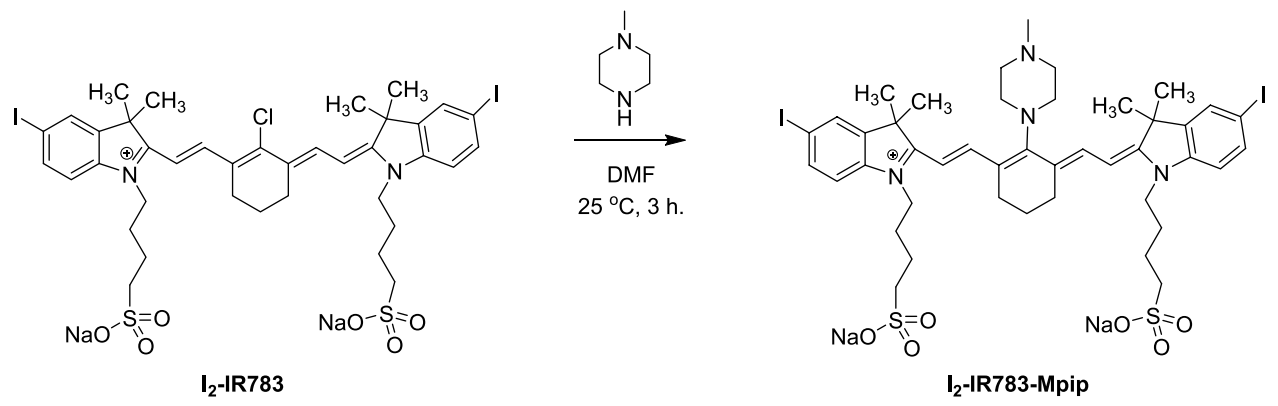

Scheme 1. Synthesis of $I_{2}$-IR783-Mpip.

selectively visualize and eradicate cancer cells ${ }^{16}$. In another study, Hcyanine was conjugated with rhodamine via disulphide linkage ${ }^{17}$. The probe, RhoSSCy, possessed dual-responsive to both thiols and $\mathrm{pH}$ with NIRF/PA dual-modal imaging, and NIR-sensitizing PDT activities in vitro and in vivo. Therefore, development of theranostic probes for precisely locating and eliminating tumour are still valuable for clinical translations.

In this work, we developed a Hcyanine based theranostic probe ( $\mathbf{I}_{2}$-IR783-Mpip) for NIR fluorescent imaging and PDT that aimed to target cancer cells via OATPs and the protonation in acidic tumour environment. Our probe showed remarkably red-shifted NIR absorbance in acidic $\mathrm{pH}$, which has not been reported elsewhere. These phenomena are beneficial for activating such PDT agent using long wavelength of light, i.e. $850 \mathrm{~nm}$, to reach highest possible penetration depth in NIR-I region ${ }^{6}$ while high fluorescence is still remained.

\section{Results}

Synthetic procedures. $\quad I_{2}$-IR783-Mpip was synthesized via conjugate addition reaction between $\mathrm{I}_{2}$-IR783 $3^{18}$ and $N$-methylpiperazine (Scheme 1). Hcyanine derivative IR783 was selected as a NIR fluorophore because of its good biocompatibility, optimized emission wavelength and intracellular uptake via OATPs. In addition, the presence of iodine atoms onto the 5-position of both terminal indole rings leads to enhancing PDT effect ${ }^{18}$. Substitution of $\mathrm{N}$-methylpiperazine group on the meso position of $\mathrm{I}_{2}$-IR783 results in achieving a $\mathrm{pH}$ response. At neutral $\mathrm{pH}$, the fluorescence of $\mathbf{I}_{2}$-IR783-Mpip is expected to be quenched by the effect from the nitrogen lone pair electrons of $N$-methylpiperazine moiety through a photoinduced electron transfer $(\mathrm{PeT})$ process ${ }^{19}$. While in acidic environments, protonation of the nitrogen atoms will block the PeT process causing the increased fluorescence signal. This compound was fully characterized by ${ }^{1} \mathrm{H}$ and ${ }^{13} \mathrm{C}$ NMR spectroscopy and high-resolution mass spectrometry (HRMS) (Fig. S1 in ESI $\dagger$ ).

Photophysical properties. Optical properties of the dye were found to be subjectable to the $\mathrm{pH}$ of the solution. I $\mathbf{2}_{2}$-IR783-Mpip absorbed light from visible to NIR region $(500-920 \mathrm{~nm}$ ), peaking at $860 \mathrm{~nm}$ under $\mathrm{pH} 6-7$. When two nitrogen atoms of $N$-methylpiperazine moiety on $\mathbf{I}_{2}$-IR783-Mpip were protonated under acidic environments ( $\mathrm{pH}$ 3.0-5.0), absorption spectra were red shifted (Fig. 1A). On the other hand, once I $\mathbf{I}_{2}$-IR783-Mpip exposed to basic environments ( $\mathrm{pH} 8.0-12.0$ ), absorption spectra were blue shifted. These phenomena could be the results from an intramolecular charge transfer (ICT) in $\mathbf{I}_{2}$-IR783-Mpip. Since the $\mathbf{I}_{2}$-IR783-Mpip contains both electron donor (amine) and acceptor (Hcyanine), a charge separation is obtained within the fluorophore. The electron-donating ability of the donor at the meso-position in a cyanine scaffold would cause absorption and/or fluorescence spectra shift ${ }^{20}$. In addition, based on the reported $\mathrm{pKa}$ values of sulfonic acid $(\mathrm{pKa}=-2.6)$ and $\mathrm{N}$-methylpiperazine $(\mathrm{pKa}=3.81 \text { and } 8.38)^{21}$, the molecular structures were proposed in three forms, $\mathrm{I}_{2}$-IR783-Mpip ${ }^{-1}, \mathrm{I}_{2}$-IR783-Mpip ${ }^{0}$, and $\mathrm{I}_{2}$-IR783-Mpip ${ }^{+1}$ in solutions $\mathrm{pH} \mathrm{8-12,6-7}$ and 3-5, respectively (Fig. 1A).

To obtain fundamental information on the effect of $\mathrm{pH}$ and charge states of $\mathbf{I}_{2}$-IR783-Mpip on the absorption spectra in Fig. 1A, quantum chemical calculations based on the density functional theory (DFT) method was applied using the 6-311 G basis set in the COSMO phase, dielectric environment 78 . Equilibrium structures of the deprotonated and protonated forms of $\mathbf{I}_{2}-\mathbf{I R 7 8 3}_{\mathbf{M p i p}} \mathbf{M}^{\mathbf{n}}(\mathrm{n}=-1,0$ and +1$)$ in the electronic ground state were computed using TURBOMOLE software package ${ }^{22}$ as shown in Fig. 1B. Frontier molecular orbital from DFT/6-311 G showed the HOMO and LUMO molecular orbitals of $\mathrm{I}_{2}$-IR783-Mpip ${ }^{-1}, \mathrm{I}_{2}$-IR783-Mpip ${ }^{0}$, and $\mathrm{I}_{2}$-IR783-Mpip ${ }^{+1}$, possible species that existed in solutions $\mathrm{pH}$ ranging from 3-12. The changes of the HOMO and LUMO in these three structures revealed that electron density on iodinated-indole rings was distributed to the IR783 backbone after excitation. In addition, the localized electron on iodinated-indole ring on the HOMO was gradually more dominant by the increase of total structural charge, suggesting the existence of a stronger charge transfer to IR783 core in acidic conditions. Therefore, the greater electron distribution from $\mathrm{I}_{2}$-IR783-Mpip ${ }^{-1}$ to $\mathrm{I}_{2}-\mathrm{IR783}-\mathrm{Mpip}^{+1}$ lead to decrease energy gap of $0.519 \mathrm{eV}$, causing the red-shift in the absorption spectra in acidic solutions. Furthermore, as confirmed by a reduced energy gap of $0.479 \mathrm{eV}$, structure with balanced charge, $\mathrm{I}_{2}$-IR783-Mpip ${ }^{0}$, was proposed as an existing form in solution $\mathrm{pH} \mathrm{6-7} \mathrm{where} \mathrm{the} \mathrm{absorbance} \mathrm{spectra} \mathrm{were} \mathrm{shown}$ in the middle (Fig. 1A). In addition, the calculated energies of $\mathrm{I}_{2}$-IR783-Mpip ${ }^{0}$ with different protonated sites of $\mathrm{N}$-substituted piperazine suggested that proton could possibly add to either nitrogen atom in the piperazine ring since the total energies of the two protonated forms are not significantly different (Fig. S2).

Next, to target tumour environments, $\mathbf{I}_{2}$-IR783-Mpip was excited at $850 \mathrm{~nm}$, where the lowest background signal can be obtained ${ }^{23,24}$, to activate the molecules in neutral and acidic conditions. As expected, strong emission 
A

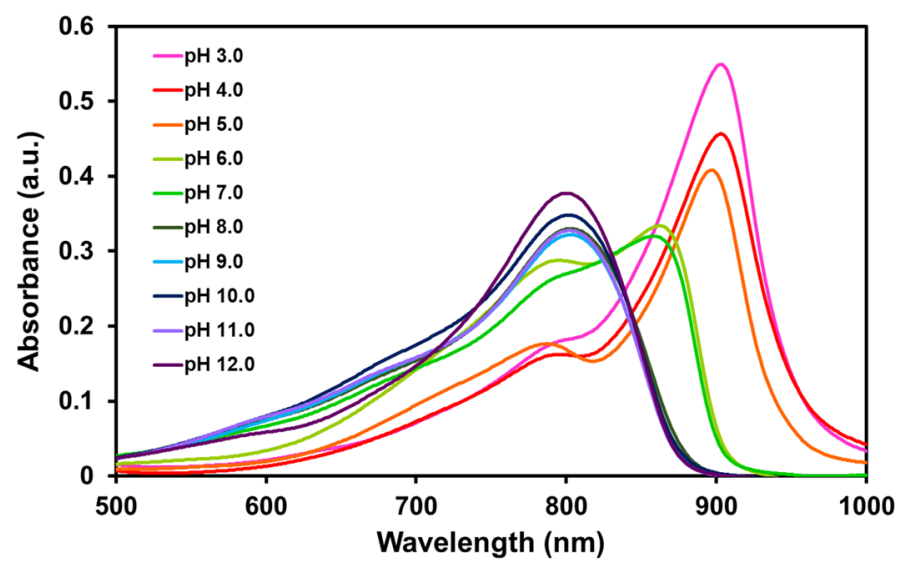

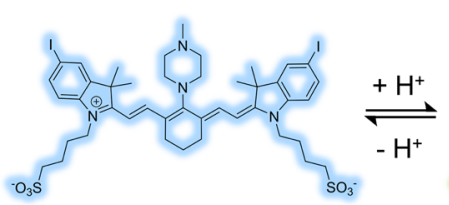

$\mathrm{pH} 8-12$

$\mathrm{I}_{2}$-IR783-Mpip ${ }^{-1}$

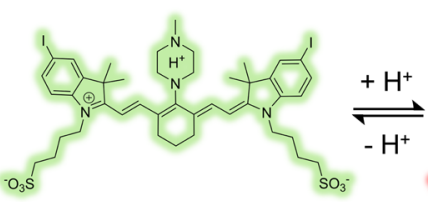

$\mathrm{pH}$ 6-7

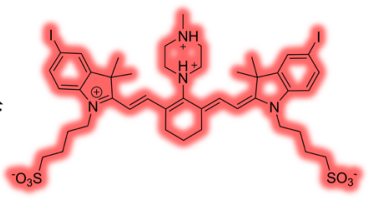

$\mathrm{pH} 3-5$

$\mathrm{I}_{2}-$ IR783-Mpip ${ }^{0}$

I - IR783-Mpip +1

B

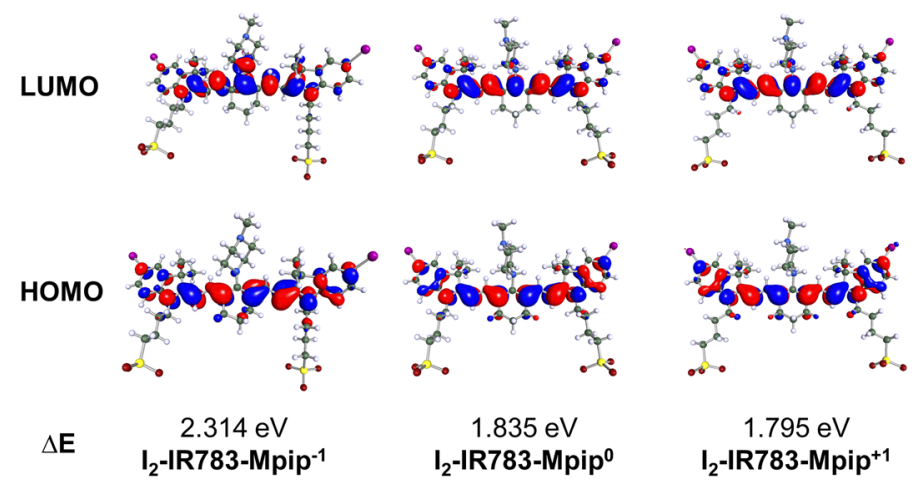

Figure 1. (A) Vis-NIR spectra of $\mathbf{I}_{2}$-IR783-Mpip and proposed structures of $\mathbf{I}_{2}$-IR783-Mpip in different $\mathbf{p H}$ (3.0-12.0). (B) Equilibrium structures of $\mathrm{I}_{2}$-IR783-Mpip ${ }^{-1}, \mathrm{I}_{2}-\mathrm{IR}_{783}-\mathrm{Mpip}^{0}$ and $\mathrm{I}_{2}-\mathrm{IR} 783-\mathrm{Mpip}^{+1}$ obtained from DFT/6-311 G geometry optimizations in the COSMO phase, dielectric environment 78. The values of the HOMO and LUMO isosurfaces are 0.025 .

intensities were only observed from the solution in $\mathrm{pH}<7.0$ (Fig. 2A). These results implied that $\mathrm{I}_{2}$-IR783-Mpip could be selectively detected at different $\mathrm{pH}$. In basic environments, the solutions turned to blue colour whereas in acidic environments $(\mathrm{pH}<6.0)$, the solutions have gradually changed to green colour which varies according to the light absorptions in the Vis-NIR absorbance spectra (Fig. 2B). Moreover, our probe demonstrated reversible optical responses in acidic and basic environments. As shown in Fig. 2C, when aqueous solution of $\mathrm{HCl}$ was dropped into an alcoholic solution of $\mathbf{I}_{2}$-IR783-Mpip, protonation occurred at the two nitrogen atoms of $\mathrm{N}$-methylpiperazine resulting in reducing of the electron-donating ability of the two nitrogen atoms causing a red shift of the absorption spectra to around $900 \mathrm{~nm}$ which made the solution turned green. On the other hand, a few drops of aqueous $\mathrm{NaOH}$ caused the protonated solution reversed back to the blue colour where the deprotonated form appeared. These results suggested that $\mathbf{I}_{2}$-IR783-Mpip could act as a reversible colour $\mathrm{pH}$ probe.

As the red shift of the spectra occurred after protonation, ${ }^{1} \mathrm{O}_{2}$ generation of $\mathbf{I}_{2}$-IR783-Mpip upon activation by NIR LED lamp under various conditions was also investigated. Singlet oxygen sensor green (SOSG) was used to detect ${ }^{1} \mathrm{O}_{2}$ that produced from the light-triggered reaction. After irradiating $\mathbf{I}_{2}$-IR783-Mpip with NIR light $\left(850 \mathrm{~nm}\right.$, light intensity $\left.30 \mathrm{~mW} / \mathrm{cm}^{2}\right)$ for $60 \mathrm{~min}$ in buffer solutions $\mathrm{pH} 5.0, \mathrm{pH} 7.0$ and $\mathrm{pH} 9.0$, emission intensities of SOSG (at $510 \mathrm{~nm}$ ) increased only in the case of the acidic solution containing $\mathbf{I}_{2}$-IR783-Mpip (Fig. 2D). The results suggested that ${ }^{1} \mathrm{O}_{2}$ was generated over irradiated time when $\mathbf{I}_{2}$-IR783-Mpip was in the acidic condition (pH 5.0) whereas significantly less amount of ${ }^{1} \mathrm{O}_{2}$ was generated in neutral and basic conditions. Moreover, singlet 

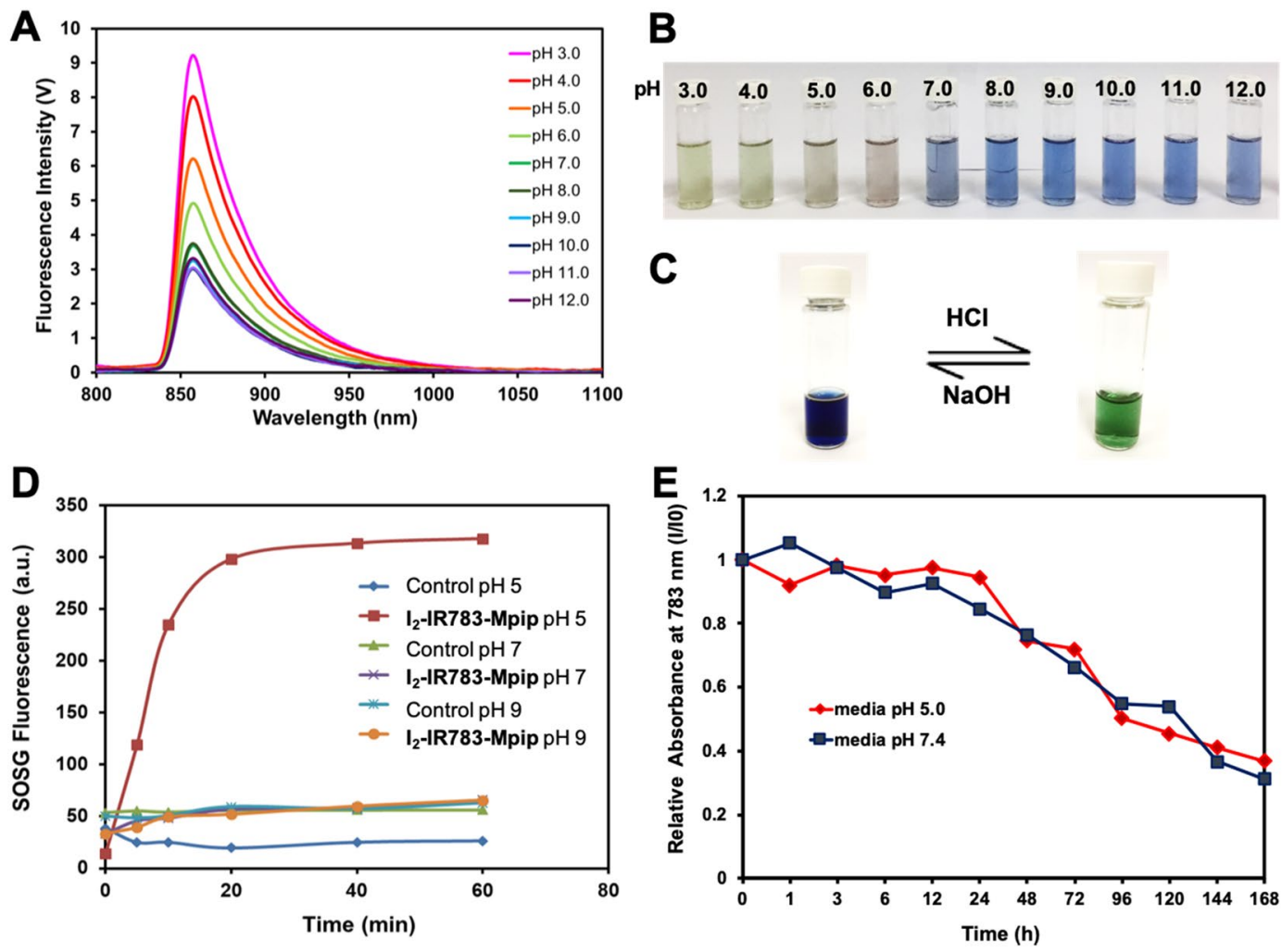

Figure 2. Optical properties of $\mathbf{I}_{2}$-IR783-Mpip. (A) Fluorescent spectra of $\mathbf{I}_{2}$-IR783-Mpip in different $\mathbf{p H}$ (3.012.0) under excitation at $\lambda 850 \mathrm{~nm}$. (B) Solutions of $\mathbf{I}_{2}$-IR783-Mpip in different $\mathrm{pH}$ (3.0-12.0). (C) Reversible colour changes of $\mathbf{I}_{2}$-IR783-Mpip in methanol solution. (D) Singlet oxygen generation of $\mathbf{I}_{2}$-IR783-Mpip upon irradiation with $850 \mathrm{~nm}$ lamp up to $60 \mathrm{~min}$. (E) Stability tests of $\mathbf{I}_{2}$-IR783-Mpip in cell culture media pH 5.0 (red line) and $\mathrm{pH} 7.4$ (blue line) at $37^{\circ} \mathrm{C}$ for up to 7 days.

oxygen quantum yield $\left(\Phi_{\Delta}\right)$ of $\mathbf{I}_{2}$-IR783-Mpip under 850-nm excitation was found to be 0.12 and 0.10 in buffer pH 5.0 and 7.0, respectively, compared to methylene blue (Fig. S3). Therefore, it is possible to apply our pH probe for cancer targeting since the tumour environments are usually acidic. Moreover, this probe could be toxic to tumour cells by generating ${ }^{1} \mathrm{O}_{2}$ only when it exposes to NIR light, $850 \mathrm{~nm}$.

Before moving to in vitro experiments, stability of $\mathbf{I}_{2}$-IR783-Mpip was also investigated in cell culture media pH 5.0 and $\mathrm{pH} 7.4$ at $37^{\circ} \mathrm{C}$ for up to 7 days (Fig. 2E). It was found that, $\mathbf{I}_{2}$-IR783-Mpip was stable under these conditions for $24 \mathrm{~h}$ and the NIR absorptions gradually decreased from day 2 to day 7. Notably, $\mathbf{I}_{2}$-IR783-Mpip exhibited similar stability profile in both cell culture media. Moreover, cell viability assay of HepG2, a human liver cancer cell line, was performed to confirm the effect of $\mathrm{pH}$ in the cell culture media. It was found that HepG2 cells maintained full viability after exposure to media $\mathrm{pH} 5.0$ for up to $12 \mathrm{~h}$. After 24 to $36 \mathrm{~h}$ incubation with media pH 5.0, the cells remained about $70 \%$ viability (Fig. S4). This implied that long time exposure to pH 5.0 media affected cell viability.

Cell internalization. In vitro experiments were performed to confirm the application of $\mathbf{I}_{2}$-IR783-Mpip in cancer cell treatment. Cell internalization and colocalization experiments were undertaken to visualize favored organelles for accumulation of $\mathbf{I}_{2}$-IR783-Mpip in HepG2 cells. As displayed in confocal images, $\mathbf{I}_{2}$-IR783-Mpip was internalized inside HepG2 and colocalized to some degree with MitoTracker Green (Pearson's R value $=0.31$ in $\mathrm{pH} 5.0$ and 0.45 in $\mathrm{pH} 7.4$ ) and much more with LysoTracker green (Pearson's $\mathrm{R}$ value $=0.68$ in $\mathrm{pH} 5.0$ and 0.68 in pH 7.4, Figs. 3A and S5). These indicated that the probe preferred to accumulate mostly in lysosomes and less in mitochondria, which is beneficial for the photosensitizer that can be activated in the acidic $\mathrm{pH}$ since in cancer cells, the lysosomal $\mathrm{pH}_{\mathrm{lys}}$ is about 3.8-4.74. Under physiological $\mathrm{pH}, \mathbf{I}_{2}$-IR783-Mpip could be transported by OATP membrane proteins ${ }^{12}$. However, in the acidic environment, $\mathrm{pH} 3-5$, the chemical structure of $\mathbf{I}_{2}$-IR783-Mpip is presented in a form of positive charges $(+1)$, therefore, the preferable uptake mechanism of the dye at $\mathrm{pH} 5.0$ could be via an active transport manner, including ATP-driven transport, but not via the OATPs. Moreover, there have been reported that the uptake mechanism of some cyanine derivatives, i.e. IR783, are related to micropinocytosis ${ }^{13,25}$.

In addition, time dependent internalization of $\mathbf{I}_{2}$-IR783-Mpip in cancer cells (HepG2) was performed in both culture media pH 5.0 and 7.4. Confocal images revealed that the uptake of $\mathbf{I}_{2}$-IR783-Mpip in HepG2 cells obviously increased within the first $12 \mathrm{~h}$ of incubation in both culture media (Fig. S6). Subsequent, to investigate tumour selectivity of $\mathbf{I}_{2}$-IR783-Mpip, quantitative cell internalization analysis of the probe in cancer cells and normal cells was performed using flow cytometry. At different $\mathrm{pH}$, the uptake of $\mathbf{I}_{2}$-IR783-Mpip by HepG2 cells 
A
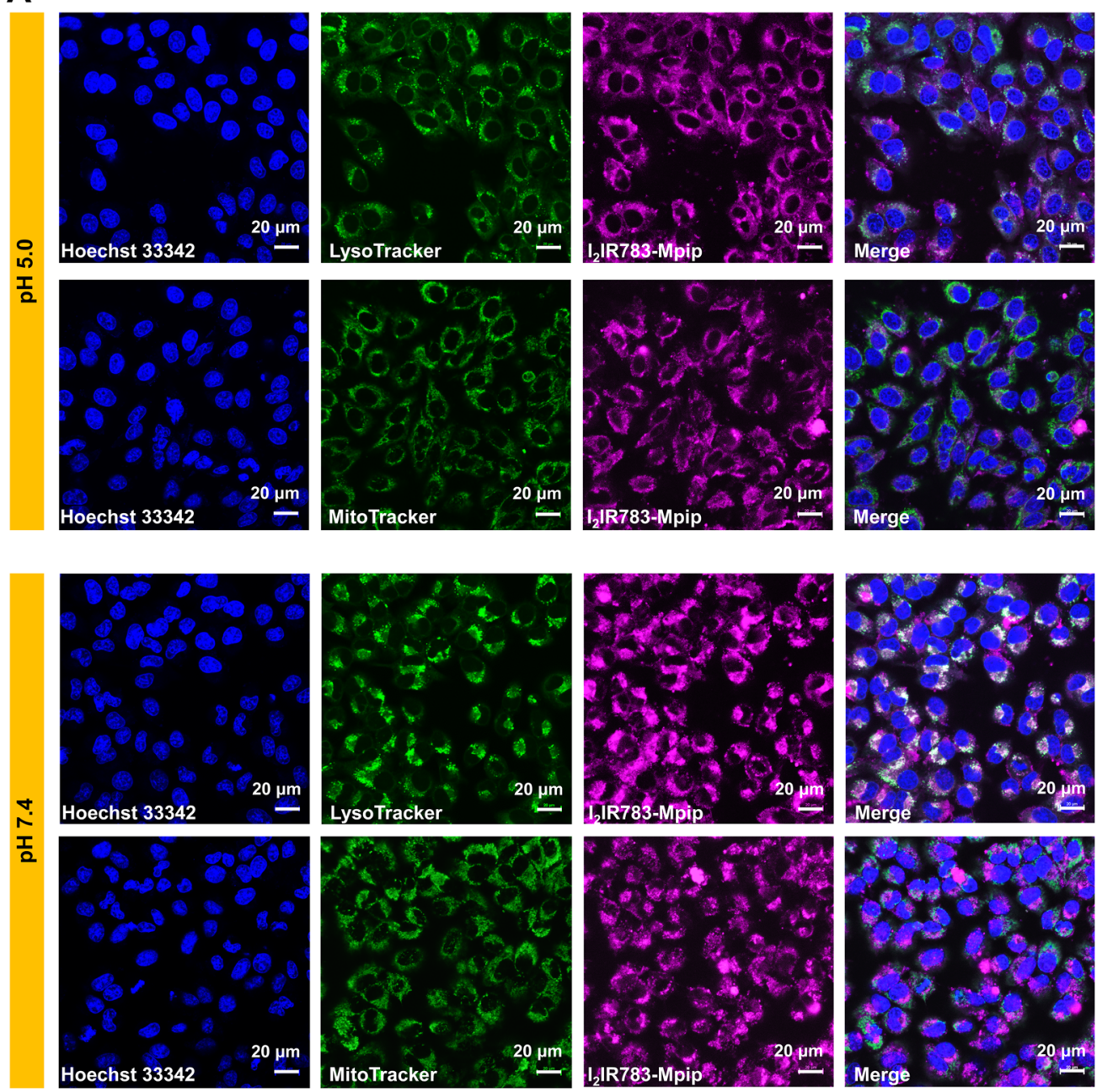

B

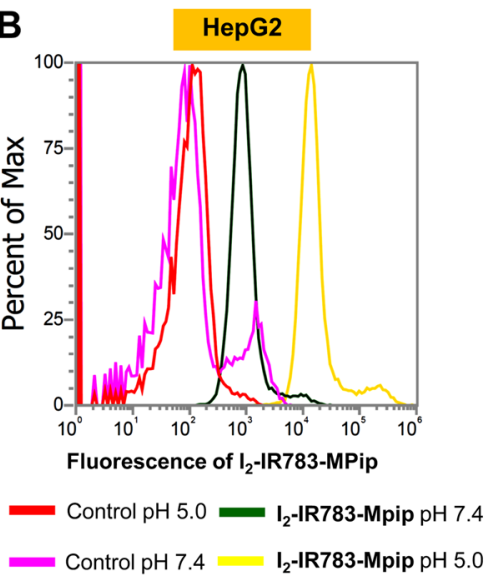

C pH 5.0
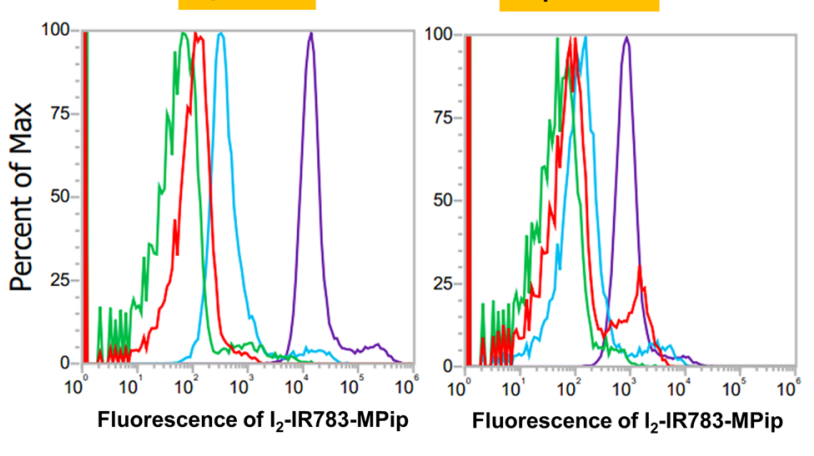

Control HepG2
$\mathrm{I}_{2}$-IR783-Mpip HEK293

- I2-IR783-Mpip HepG2

Figure 3. (A) Confocal images of HepG2 cells incubated with $30 \mu \mathrm{M}$ of $\mathbf{I}_{\mathbf{2}}$-IR783-Mpip for $6 \mathrm{~h}$ and colocalization of $\mathbf{I}_{2}$-IR783-Mpip with LysoTracker green (Pearson's R value $=0.68$ in pH 5.0 and 0.68 in pH 7.4) and MitoTracker Green (Pearson's R value $=0.31$ in pH 5.0 and 0.45 in pH 7.4). (B) Flow cytometry of HepG2 cells incubated with $15 \mu \mathrm{M}$ of $\mathbf{I}_{2}$-IR783-Mpip for $12 \mathrm{~h}$ in culture media pH 5.0 and 7.4. (C) Flow cytometry of HepG2 and HEK293 cells incubated with $15 \mu \mathrm{M}$ of $\mathbf{I}_{2}$-IR783-Mpip for $12 \mathrm{~h}$ in culture media $\mathrm{pH} 5.0$ and 7.4. Scale bars $=20 \mu \mathrm{m}$.

was much higher in media pH 5.0 than that in media 7.4 (Fig. 3B). By comparison, at concentration of $15 \mu \mathrm{M}$ and $12 \mathrm{~h}$ incubation, the uptake of $\mathbf{I}_{\mathbf{2}}$-IR783-Mpip in normal cells (Human embryonic kidney 293 cells, HEK293) was significantly less than the one in HepG2 cells in both media conditions (pH 5.0 and pH 7.4, Fig. 3C). Therefore, $I_{2}$-IR783-Mpip could be a cancer targeted agent that have potential in selective destroying cancer cells via PDT. 
A

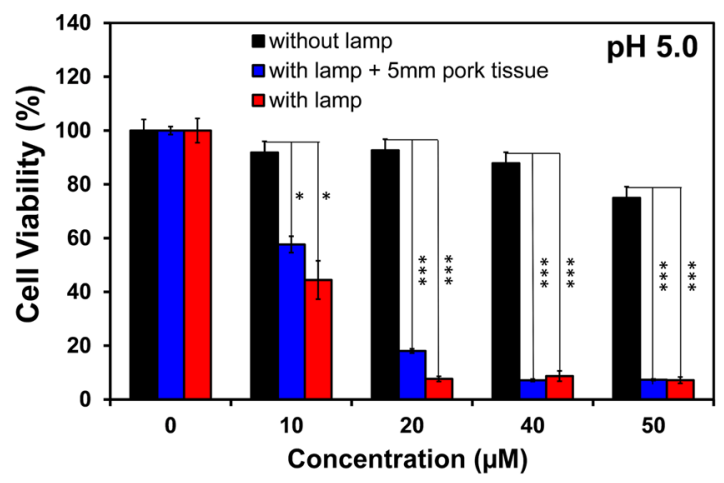

B

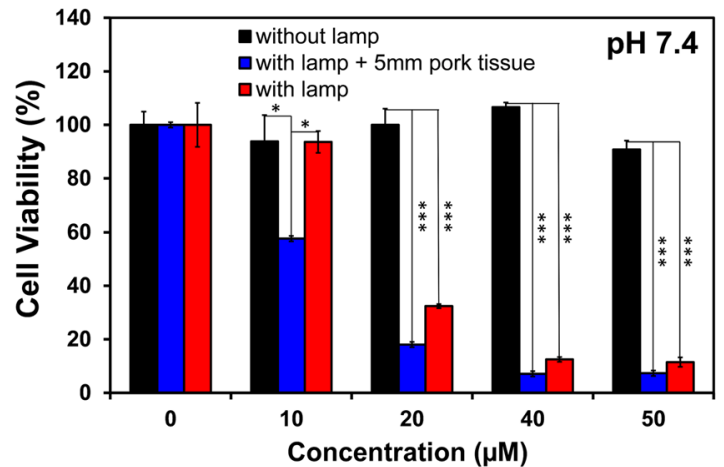

C

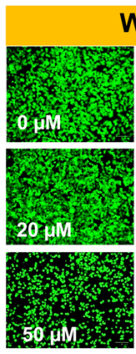

Calcein AM
Without Light

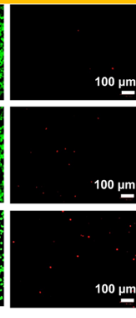

PI

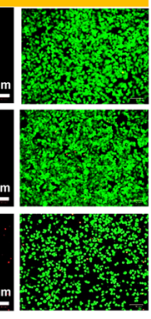

Merge

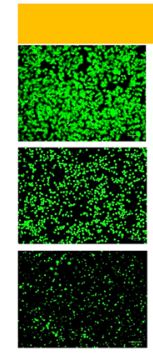

Calcein AM
With Light

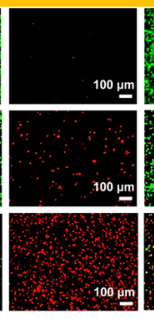

PI

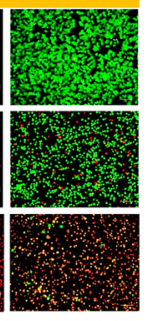

Merge

Figure 4. Photodynamic therapy effect of $\mathbf{I}_{2}$-IR783-Mpip. Relative viabilities of HepG2 cells in media (A) $\mathrm{pH}$ 5.0 and (B) pH 7.4; red bars represent cells irradiated with 850 lamp, blue bars represent cells covered by $5 \mathrm{~mm}$ pork tissue with $850 \mathrm{~nm}$ light irradiation and black bars represent cells without irradiation. (C) LIVE/DEAD viability/cytotoxicity assay of $\mathbf{I}_{2}$-IR783-Mpip under dark and light conditions at various concentrations $(0,20$ and $50 \mu \mathrm{M})$. Scale bars $=100 \mu \mathrm{m}$. Statistical analysis are based on one-way ANOVA followed by Tukey's posthoc analysis $(* \mathrm{P}<0.05, * * \mathrm{P}<0.01, * * * \mathrm{P}<0.001)$.

Photodynamic therapy. In general, PDT agents should be harmless in the dark state but highly toxic once being exposed to the specific light. To study the photocytotoxicity of $\mathbf{I}_{\mathbf{2}}$-IR783-Mpip, HepG2 cells were incubated with various concentrations of $\mathbf{I}_{2}$-IR783-Mpip for $6 \mathrm{~h}$ in both media $\mathrm{pH} 5.0$ and $\mathrm{pH} 7.4$, exposed to $850 \mathrm{~nm}$ LED light $\left(30 \mathrm{~mW} / \mathrm{cm}^{2}\right)$ for $30 \mathrm{~min}$, and then re-incubated in the dark for another $12 \mathrm{~h}$, respectively. Relative viabilities of the cells exposed to $850 \mathrm{~nm}$ light were confirmed to be inversely proportional to the concentrations of $\mathbf{I}_{2}$-IR783-Mpip in both culture media conditions. Cell viability assay revealed that no significant dark cytotoxicity of $\mathbf{I}_{2}$-IR783-Mpip was observed even at high concentration up to $50 \mu \mathrm{M}$ in both culture media ( $\mathrm{pH} 5.0$ and $\mathrm{pH}$ 7.4, Fig. 4A,B). In contrast, normal cells HEK293 incubated with $\mathbf{I}_{2}$-IR783-Mpip maintained viability even after $850 \mathrm{~nm}$ light exposure for $30 \mathrm{~min}$ in both culture media (Fig. S7), indicating that $\mathbf{I}_{\mathbf{2}}$-IR783-Mpip was selectively toxic to cancer cells after illumination.

To investigate whether the NIR absorbed $\mathbf{I}_{2}$-IR783-Mpip could be activated in deep-seated tumour cells, a piece of $5 \mathrm{~mm}$ pork tissue was placed between cells and the light source. After light exposure, HepG2 cell viabilities decreased in a dose dependent manner (Fig. 4A,B), which were similar to those results when there was no pork tissue covered on the cells. These observations strongly suggested that $\mathbf{I}_{2}$-IR783-Mpip could selectively destroy deep-seated cancer cells when it was irradiated with $850 \mathrm{~nm}$ LED light for $30 \mathrm{~min}$ in both physiological and slightly acidic environments.

To further confirm the effectiveness of $\mathbf{I}_{2}$-IR783-Mpip in terminating cancer cells under light irradiation, LIVE/DEAD viability/cytotoxicity assay was performed. HepG2 cells were plated in a 6-well plate and incubated for $24 \mathrm{~h}$ before adding $\mathrm{I}_{2}$-IR783-Mpip, at $20 \mu \mathrm{M}$ and $50 \mu \mathrm{M}$, and then re-incubated for another $6 \mathrm{~h}$. After that, the 


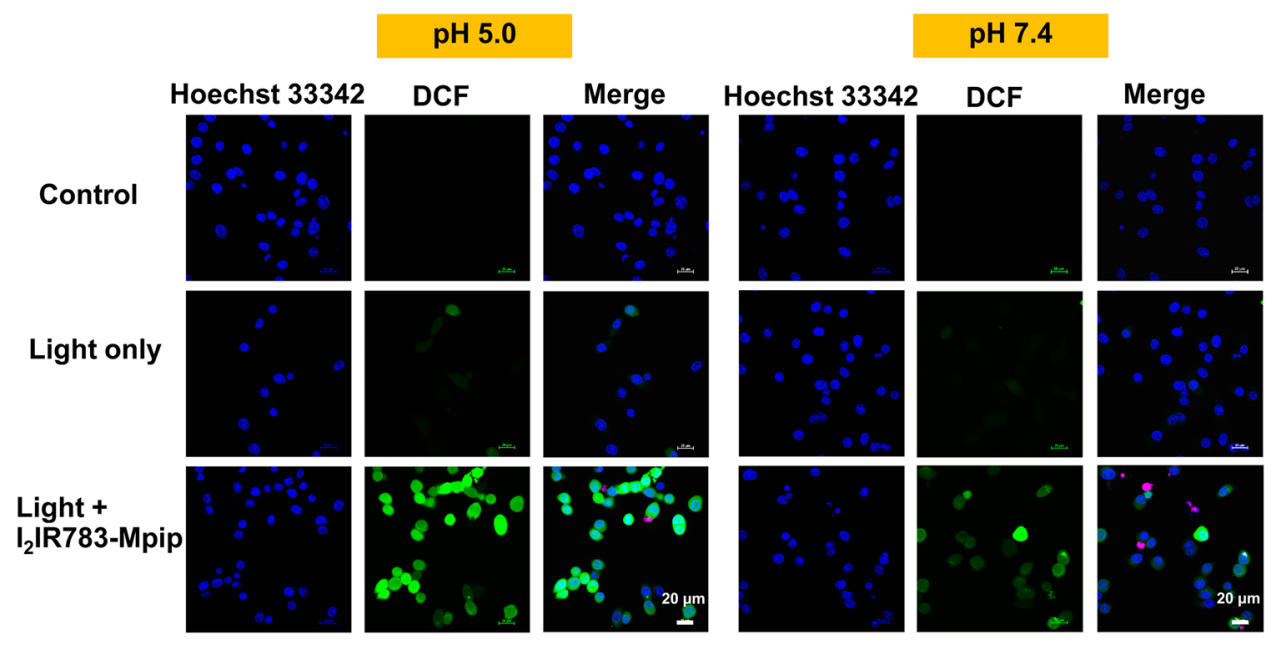

Figure 5. Detection of intracellular reactive oxygen species generated by $\mathbf{I}_{2}$-IR783-Mpip $(20 \mu \mathrm{M})$ at pH 5.0 and 7.4 in HepG2 cells using DCFDA cellular ROS detection assay. Scale bars $=20 \mu \mathrm{m}$.

cells were exposed to $850 \mathrm{~nm}$ light for $30 \mathrm{~min}$ before staining with calcein AM and propidium iodide (PI). Calcein AM can easily enter the live cells and emit a strong green fluorescence after being excited with a $495 \mathrm{~nm}$ laser, whereas PI can easily enter the dead cells, bind to DNA by intercalating between the bases and emit a strong red fluorescence after being excited with a $535 \mathrm{~nm}$ laser. Visualization by an inverted fluorescence microscope, the increased red fluorescence was observed with the increased amount of $\mathbf{I}_{2}$-IR783-Mpip incubated in cells after irradiation with $850 \mathrm{~nm}$ light, indicating that more dead cell populations occurred when increasing the dose of $I_{2}$-IR783-Mpip. Fluorescence from Calcein AM and PI co-stained cells confirmed the effectiveness of photodynamic cancer cell ablation induced by $\mathbf{I}_{2}$-IR783-Mpip in media at pH 5.0 (Fig. 4C) and pH 7.4 (Fig. S8).

Furthermore, intracellular reactive oxygen species (ROS) generation was also observed from the cell culture contained $\mathbf{I}_{2}$-IR783-Mpip after irradiated with $850 \mathrm{~nm}$ light. HepG2 cells were treated with $\mathbf{I}_{2}$-IR783-Mpip for $6 \mathrm{~h}$ in both media (pH 5.0 and 7.4), stained with 2,7-dichloro-dihydro-fluorescein diacetate (DCFH-DA) and then exposed to $850 \mathrm{~nm}$ light for $20 \mathrm{~min}$. DCFH-DA can be oxidized by intracellular ROS to produce 2,7-dichloro-dihydro-fluorescein (DCF). Intracellular DCF can be detected by fluorescence confocal microscopy using $488 \mathrm{~nm}$ excitation to obtain a strong green fluorescence. The confocal images showed the production of DCF was significantly increased in the presence of light exposure and $\mathbf{I}_{2}$-IR783-Mpip in both culture media but more obvious in media pH 5.0 than the one in $\mathrm{pH} 7.4$ (Fig. 5). In addition, higher amount of green fluorescence could be detected from more acidic environment (Fig. S9).

\section{Conclusions}

In summary, $\mathbf{I}_{2}$-IR783-Mpip was successfully developed as a $\mathrm{pH}$ sensitive theranostic agent for fluorescent imaging and PDT. The probe exhibited red-shifted Vis-NIR absorbance spectra under acidic conditions and blue-shifted in basic conditions. Upon exposure to $850 \mathrm{~nm}$ LED light for $30 \mathrm{~min}, \mathbf{I}_{2}$-IR783-Mpip generated higher amount of ${ }^{1} \mathrm{O}_{2}$ in more acidic environment. Moreover, $\mathbf{I}_{2}$-IR783-Mpip selectively internalized cancer cells and the uptake was in dose- and time-dependence manners. At concentration as low as $20 \mu \mathrm{M}, \mathbf{I}_{2}$-IR783-Mpip showed light induced cytotoxicity to HepG2 cells resulting to about 10 and $30 \%$ viabilities in acidic and physiological conditions, respectively. In addition, under simulated deep-tissue setting, $\mathbf{I}_{2}$-IR783-Mpip still maintained its PDT efficiency towards cancer cells. Better reactive oxygen species generation of $\mathbf{I}_{2}$-IR783-Mpip was found inside the cells in the acidic environment ( $\mathrm{pH}$ 5.0) compared with those in the neutral one ( $\mathrm{pH} 7.4$ ). Based on all results, $I_{2}$-IR783-Mpip could be a good candidate for tumour environment targeting agent for photodynamic treatment.

\section{Methods}

Synthesis of $\mathrm{I}_{2}$-IR783-Mpip. $\quad \mathrm{I}_{2}$-IR783 $(46.60 \mathrm{mg}, 0.046 \mathrm{mmol})$ was dissolved in anhydrous DMF $(4.0 \mathrm{~mL})$, and then $N$-methylpiperazine $(4.60 \mathrm{mg}, 0.046 \mathrm{mmol})$ was added to the solution. Thereafter, the mixture was stirred at room temperature for $3 \mathrm{~h}$ under nitrogen atmosphere. After that, the solvent was removed under reduced pressure and the crude product was purified by column chromatography using $\mathrm{CH}_{2} \mathrm{Cl}_{2}: \mathrm{MeOH}$ (gradient from ratio 9:1 to 7:3) as the eluent to afford a blue solid (40.2 mg, 80.4\%). ${ }^{1} \mathrm{H}$ NMR (500 MHz, DMSO-d6): $\delta 7.93$ (s, $1 \mathrm{H}, \mathrm{Ar}-\mathrm{CH}), 7.70(\mathrm{dd}, J=8.5,1.5,1 \mathrm{H}, \mathrm{Ar}-\mathrm{CH}), 7.60(\mathrm{~d}, J=12.0,1 \mathrm{H}, \mathrm{CH}), 7.15(\mathrm{~d}, J=8.5,1 \mathrm{H}, \mathrm{Ar}-\mathrm{CH}), 5.98$ $(\mathrm{d}, J=13.0,1 \mathrm{H}, \mathrm{CH}), 4.04\left(\mathrm{~s}, 2 \mathrm{H}, \mathrm{N}-\mathrm{CH}_{2}\right), 3.84\left(\mathrm{~s}, 2 \mathrm{H}, \mathrm{N}-\mathrm{CH}_{2}\right), 2.69\left(\mathrm{~s}, 2 \mathrm{H}, \mathrm{N}-\mathrm{CH}_{2}\right), 2.55\left(\mathrm{~s}, 3 \mathrm{H}, \mathrm{N}-\mathrm{CH}_{3}\right), 2.40$ (s, $\left.2 \mathrm{H}, \mathrm{N}-\mathrm{CH}_{2}\right), 1.67-1.83$ (m, 16H). ${ }^{13} \mathrm{C}$ NMR (125 MHz, DMSO-d6): $\delta 171.4,166.8,148.3,143.5,142.7,142.0$, $140.5,136.8,130.8,127.1,124.1,113.9,95.8,89.6,60.6,50.9,49.0,47.5,45.8,42.7,31.9,28.32$, 28.2, 25.5, 22.6. HRMS-ESI (m/z): the calculated value (calcd) for $\mathrm{C}_{43} \mathrm{H}_{55} \mathrm{I}_{2} \mathrm{~N}_{4} \mathrm{Na}_{2} \mathrm{O}_{6} \mathrm{~S}_{2}{ }^{+}\left[\mathrm{M}^{+}\right]$: 1087.1442, found 1087.1449.

General details for Vis-NIR and fluorescence measurements. Preparation of the stock solutions: The stock solution of $\mathbf{I}_{\mathbf{2}}$-IR783-Mpip was prepared by dissolving $2.2 \mathrm{mg}$ of $\mathbf{I}_{2}$-IR783-Mpip with methanol in a 
$3 \mathrm{~mL}$ standard micro volumetric flask $\left(6.7 \times 10^{-4} \mathrm{M}\right)$. The UV-Vis-NIR and fluorescence measurements were performed by taking appropriate amount of this stock solution.

Vis-NIR absorption measurement: The stock solution of $\mathbf{I}_{2}$-IR783-Mpip $(20 \mu \mathrm{L})$ was added to $3 \mathrm{~mL}$ of buffer solutions at various $\mathrm{pH}(\mathrm{pH} 3-12)$ in a $3.5 \mathrm{~mL}$ quartz cuvette (final concentration $=4.5 \mu \mathrm{M})$. The UV-Vis-NIR absorption spectra were recorded by a Cary Series UV-Vis-NIR spectrophotometer (Agilent Tech, Santa Clara, CA, USA).

Fluorescence measurement: The stock solution of $\mathbf{I}_{2}$-IR783-Mpip $(20 \mu \mathrm{L})$ was added to $3 \mathrm{~mL}$ of buffer solutions at various $\mathrm{pH}(\mathrm{pH} 3-12)$ in a $3.5 \mathrm{~mL}$ quartz cuvette (final concentration $=4.5 \mu \mathrm{M})$. The fluorescence spectra were recorded by PTI QuantaMaster 500 - Near Infra-Red Photoluminescence System (HORIBA Scientific), using the following parameters: excitation wavelengths $=850 \mathrm{~nm}$, excitation slit widths $=10 \mathrm{~nm}$, and emission slit widths $=10 \mathrm{~nm}$.

Singlet oxygen generation. Singlet oxygen sensor green (SOSG) $10 \mu \mathrm{L}(0.5 \mathrm{mM})$ was added into solutions of $\mathbf{I}_{2}$-IR783-Mpip $(30 \mu \mathrm{M})$ in buffers pH 5.0, 7.0 and 9.0. Then, the solution was exposed to a NIR lamp $(850 \mathrm{~nm})$ at light intensity of $30 \mathrm{~mW} \mathrm{~cm}^{-2}$ for 5, 10, 20, 40, and $60 \mathrm{~min}$. Buffers pH 5.0, 7.0 and 9.0 without $\mathbf{I}_{2}$-IR783-Mpip were also carried out as controls using the same method. Finally, fluorescent intensities of SOSG were measured at an excitation of $494 \mathrm{~nm}$ using Fluorescence microplate reader (Thermoscientific/VARIOSKAN LUX). Data were reported within error bars of three replicates experiments.

Singlet oxygen quantum yield determination. Singlet oxygen generation of $\mathbf{I}_{2}$-IR783-Mpip was determined using $850 \mathrm{~nm}$ LED lamp. Sample solutions were prepared in phosphate buffer pH 5.0 and 7.4 at a concentration of $15 \mu \mathrm{M}$ in a 6- well plate. 1,3-Diphenylisobenzofuran (DPBF, $1 \mathrm{mM}$ ) was prepared in DMSO and diluted to $70 \mu \mathrm{M}$ in buffer solutions. The decrease in absorbance was measured at $418 \mathrm{~nm}$ every $1 \mathrm{~min}$ for $10 \mathrm{~min}$ by a BMG Labtech/SpeeTrostar Nano microplate reader. The rate of change of absorbance is plotted against irradiation time.

$$
\Phi_{\mathrm{x}}=\Phi_{\mathrm{st}}\left(\operatorname{grad}_{\mathrm{x}} / \operatorname{grad}_{\mathrm{st}}\right)\left(\mathrm{F}_{\mathrm{st}} / \mathrm{F}_{\mathrm{x}}\right)
$$

$\Phi_{\text {st }}$ represents the quantum yield of the standard; $\Phi_{\mathrm{x}}$ represents the quantum yield of the unknown, and grad is the slope of the best linear fit. F stands for the absorption correction factor $\left(\mathrm{F}=1-10^{-\mathrm{abs}}\right.$; abs represents absorbance), and subscripts $\mathrm{x}$ and st denote the unknown and the standard, respectively.

Stability test. Solutions of $\mathbf{I}_{2}$-IR783-Mpip $(15 \mu \mathrm{M})$ in 5\% FBS in DMEM cell culture media at pH 5.0 and pH 7.4 were incubated at $37^{\circ} \mathrm{C}$ for up to $168 \mathrm{~h}$ or 7 days. Vis-NIR spectra of the solutions were measured at different time points including $0,1,3,6,12,24,48,72,96,120,144$, and $168 \mathrm{~h}$ respectively.

Cell culture. Human hepatoma cancer cells (HepG2) and human embryonic kidney 293 (HEK-293) cells were cultured on $75 \mathrm{~cm}^{2}$ culture flasks in Dulbecco's Modified Eagle Medium/High glucose (DMEM/HIGH GLUCOSE, GE healthcare Life Sciences HyClone Laboratories) supplemented with $10 \%$ fetal bovine serum (FBS, Gibco) and $1 \%$ Penicillin Streptomycin Solution 100X (CORNING). All cells were cultured in a humidified incubator at $37^{\circ} \mathrm{C}$ with $5 \% \mathrm{CO}_{2}$.

Cell survival assay of HepG2 cells in media 5.0. For cell survival assay, HepG2 cells were seeded into 96-well cell culture plates at $7 \times 10^{3} /$ well and incubated for $24 \mathrm{~h}$ at $37^{\circ} \mathrm{C}$ under $5 \% \mathrm{CO}_{2}$. After that, cell culture media were replaced with 5\% FBS DMEM pH 5.0 at various incubation time $(1,3,6,12,24,36 \mathrm{~h})$ and cells cultured in 5\% FBS DMEM pH 7.4 were used as control. After incubation, the cell viabilities were measured using previously reported MTT protocol ${ }^{26}$. Briefly, the cells were washed with PBS ( 3 times) before being treated with methylthiazolyldiphenyl-tetrazolium bromide $(20 \mu \mathrm{L}, 0.5 \mathrm{mg} / \mathrm{mL}$, Sigma-Aldrich $)$ for $2 \mathrm{~h}$. Then, culture media were replaced with DMSO and the cell viabilities were determined through UV-vis absorption of the resulting formazan at wavelength $560 \mathrm{~nm}$ using microplate reader (BMG Labtech/SPECTROstar Nano).

Live cell imaging. HepG2 cells were seeded at a density of $7 \times 10^{3}$ cells per well in 8 -well Chambered Coverglass with non-removable wells (Nunc Lab-Tek II Chamber Slide) and incubated for $24 \mathrm{~h}$ at $37^{\circ} \mathrm{C}$ under $5 \% \mathrm{CO}_{2}$. After that, cell culture media were removed and solutions of $\mathbf{I}_{2}$-IR783-Mpip in DMEM with 5\% FBS at $\mathrm{pH} 5.0$ and $\mathrm{pH} 7.4$ with final concentrations of $30 \mu \mathrm{M}$ were added. After 1, 3, 6, 12 and $24 \mathrm{~h}$ incubation, the cells were washed three times with PBS to remove the non-uptake dye. Thereafter, the cells were stained with $1.0 \mu \mathrm{M}$ Hoechst 33342 (Thermo Fisher Scientific) for $10 \mathrm{~min}$. All cells were brought to image under Laser Scanning

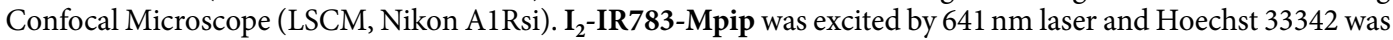
excited by $405 \mathrm{~nm}$ laser. A $60 \mathrm{X}$ oil immersion objective lens was used.

Colocalization study. After seeding the cells in an 8-well Chambered Coverglass and incubated for $24 \mathrm{~h}$ at $37^{\circ} \mathrm{C}$ under $5 \% \mathrm{CO}_{2}$, the cells were incubated with $30 \mu \mathrm{M}$ of $\mathbf{I}_{2}$-IR783-Mpip in DMEM with 5\% FBS at pH 5.0 and $\mathrm{pH} 7.4$ for another $12 \mathrm{~h}$, washed three times with PBS, and incubated with Lysotracker Green DND 26, Mitotracker Green FM (Thermo Fisher Scientific) for $20 \mathrm{~min}$. The cells were washed again before staining with Hoechst 33342 for $10 \mathrm{~min}$. After that, cells were visualized under LSCM: I laser; Lysotracker and Mitotracker was excited by $488 \mathrm{~nm}$ laser; and Hoechst 33342 was excited by $405 \mathrm{~nm}$ laser. A 60 X oil immersion objective lens was used. To quantify the colocalization of $\mathbf{I}_{2}$-IR783-Mpip and organelles trackers, we obtained the intensities of the red and green channels from each pixel of the confocal image, corresponding to the excitations from $\mathbf{I}_{2}$-IR783-Mpip and organelles trackers, respectively, and calculate the Pearson's 
correlation coefficient between the two intensities. The computation was carried out in python, using a built-in function from scipy statistical package.

Flow cytometry. HepG2 and Hek 293 cells were seeded into 6-well cell culture plates density of $2 \times 10^{5}$ cells/ well and incubated for $48 \mathrm{~h}$ at $37^{\circ} \mathrm{C}$ under $5 \% \mathrm{CO}_{2}$. After that, cell culture media were removed and solutions of $\mathbf{I}_{2}$-IR783-Mpip in DMEM with 5\% FBS at pH 5.0 and pH 7.4 with final concentrations of $15 \mu \mathrm{M}$ were added. After $12 \mathrm{~h}$ incubation, culture media were removed, and the cells were thoroughly washed with PBS. Thereafter, the cells were harvested by trypsinization whose action was stopped with $10 \%$ FBS in DMEM cell-culture media. The cells were then transferred into Eppendorf tubes and washed three times with ice cold PBS to remove the non-uptake dye by centrifugation at $800 \mathrm{~g}, 4^{\circ} \mathrm{C}$ for $5 \mathrm{~min}$ and resuspended in $1 \mathrm{~mL}$ of fresh ice-cold PBS. Then 20,000 events (cells) were analyzed by flow cytometry using an Attune NxT Flow Cytometer (Life Technologies) using red excitation laser $637 \mathrm{~nm}$ and emission filter $780 / 60 \mathrm{~nm}$.

Light induced cytotoxicity. In vitro cell viability was measured using a standard methyl thiazolyltetrazolium (MTT) assay. HepG2 and Hek293 cells were seeded into 96 -well cell culture plates at $7 \times 10^{3}$ cells/well and incubated for $24 \mathrm{~h}$ at $37^{\circ} \mathrm{C}$ under $5 \% \mathrm{CO}_{2}$. After that, cell culture media were removed and solutions of $\mathbf{I}_{2}$-IR783-Mpip in DMEM with 5\% FBS at pH 5.0 and $\mathrm{pH} 7.4$ with various concentrations $(0,10,20,40,50 \mu \mathrm{M})$ were added and the cells were continued incubation for another $6 \mathrm{~h}$. Thereafter, the cells were irradiated by an $850 \mathrm{~nm}$ lamp with light intensity of $30 \mathrm{~mW} / \mathrm{cm}^{2}$ for $30 \mathrm{~min}$ before re-incubation for another $12 \mathrm{~h}$. In the case of deep-tissue simulation, a piece of 5-mm pork slice (sterile with $95 \%$ alcohol) was placed on the top of 96-well plate to insert between the cells and the lamp before irradiation. After incubation, the cell viabilities were measured using standard MTT protocol ${ }^{26}$ and the absorption of formazan was measured at wavelength $560 \mathrm{~nm}$ using microplate reader (BMG Labtech/SPECTROstar Nano).

For LIVE/DEAD viability/cytotoxicity assay, HepG2 cells were seeded into 6-well cell culture plates at a density of $2 \times 10^{5}$ cells/well and incubated for $24 \mathrm{~h}$ at $37^{\circ} \mathrm{C}$ under $5 \% \mathrm{CO}_{2}$. After that, cell culture media were removed and solutions of $\mathbf{I}_{2}$-IR783-Mpip in DMEM with 5\% FBS at pH 5.0 and pH 7.4 with final concentrations of $20 \mu \mathrm{M}, 50 \mu \mathrm{M}$ were added. After $6 \mathrm{~h}$ incubation, the cells were irradiated by an $850 \mathrm{~nm}$ lamp with light intensity of $30 \mathrm{~mW} / \mathrm{cm}^{2}$ for $30 \mathrm{~min}$ before re-incubation for another $12 \mathrm{~h}$. Thereafter, the cells were stained with $4 \mu \mathrm{M}$ calcein AM and propidium iodide (PI) (Thermo Fisher Scientific) for $5 \mathrm{~min}$, and then imaged by Fluorescence microscope (BioRad/Zoe) using $490 \mathrm{~nm}$ excitation and $515 \mathrm{~nm}$ emission filters for calcein AM and $535 \mathrm{~nm}$ excitation and $615 \mathrm{~nm}$ emission filters for PI.

Cellular reactive oxygen production. HepG2 cells were seeded at a density of $7 \times 10^{3}$ cells per well in 8 -well Chambered Coverglass with non-removable wells and incubated for $24 \mathrm{~h}$ at $37^{\circ} \mathrm{C}$ under $5 \% \mathrm{CO}_{2}$. After that, cell culture media were removed and solutions of $\mathbf{I}_{2}$-IR783-Mpip $(20 \mu \mathrm{M})$ in DMEM with 5\% FBS at pH 5.0 and $\mathrm{pH} 7.4$ were added. After $6 \mathrm{~h}$ incubation, the cells were washed three times with PBS to remove the non-uptake dye and then $20 \mu \mathrm{M}$ of 2,7-dichloro-dihydro-fluorescein diacetate (DCFH-DA, Sigma-Aldrich) was added into the cells. After incubation for $1 \mathrm{~h}$, the cells were washed three times with PBS to remove the non-uptake DCFH-DA dye before irradiation with an $850 \mathrm{~nm}$ lamp for $20 \mathrm{~min}$. Before imaging, the cells were stained with $1.0 \mu \mathrm{M}$ Hoechst 33342 (Thermo Fisher Scientific) for $10 \mathrm{~min}$ then fluorescence of the resulting 2,7-dichloro-dihydro-fluorescein (DCF) was monitored using $488 \mathrm{~nm}$ excitation laser and Hoechst 33342 was excited at $405 \mathrm{~nm}$ under Laser Scanning Confocal Microscope (Nikon A1Rsi). A 60 X oil immersion objective lens was used.

For quantitative analysis, HepG2 cells were seeded into 96 -well cell culture plates at $7 \times 10^{3} /$ well and incubated for $24 \mathrm{~h}$ at $37^{\circ} \mathrm{C}$ under $5 \% \mathrm{CO}_{2}$. After that, cell culture media were removed and solutions of $\mathbf{I}_{2}$-IR783-Mpip $(20 \mu \mathrm{M})$ in DMEM with 5\% FBS at $\mathrm{pH} 5.0$ and $\mathrm{pH} 7.4$ with various concentration $(0,10,20,40,50 \mu \mathrm{M})$ were added. After $6 \mathrm{~h}$ incubation, the cells were washed three times with PBS before being irradiated by $850 \mathrm{~nm}$ lamp for $20 \mathrm{~min}$. Thereafter, $20 \mu \mathrm{M}$ of DCFH-DA was added into each well and the cells were continue incubated for another $45 \mathrm{~min}$. Fluorescent end point of the DCF production was recorded at $495 \mathrm{~nm}$ excitation and $529 \mathrm{~nm}$ emission using a Fluorescence microplate reader (Thermo Fisher Scientific/VARIOSKAN LUX).

Statistical analysis. Data are illustrative of three independent experiments and presented as the mean of four individual observations $(n=4)$ with the standard deviation $($ mean $\pm S D)$. The statistical analysis was performed using one-way ANOVA followed by Tukey's post-hoc analysis. P values $<0.05$ were considered to indicate significance $(* \mathrm{P}<0.05, * * \mathrm{P}<0.01, * * * \mathrm{P}<0.001)$.

Received: 18 October 2019; Accepted: 13 January 2020;

Published online: 28 January 2020

\section{References}

1. Dolmans, D. E., Fukumura, D. \& Jain, R. K. Photodynamic therapy for cancer. Nat. Rev. Cancer 3, 380-387, https://doi.org/10.1038/ $\operatorname{nrc1071}(2003)$

2. Hao, G. Y., Xu, Z. P. \& Li, L. Manipulating extracellular tumour pH: an effective target for cancer therapy. Rsc Adv. 8, 22182-22192, https://doi.org/10.1039/c8ra02095g (2018).

3. Persi, E. et al. Systems analysis of intracellular pH vulnerabilities for cancer therapy. Nat. Commun. 9, 2997, https://doi.org/10.1038/ s41467-018-05261-x (2018).

4. Kroemer, G. \& Jaattela, M. Lysosomes and autophagy in cell death control. Nat. Rev. Cancer 5, 886-897, https://doi.org/10.1038/ nrc1738 (2005)

5. Luo, S., Zhang, E., Su, Y., Cheng, T. \& Shi, C. A review of NIR dyes in cancer targeting and imaging. Biomater. 32, 7127-7138, https:// doi.org/10.1016/j.biomaterials.2011.06.024 (2011).

6. Weissleder, R. A clearer vision for in vivo imaging. Nat. Biotechnol. 19, 316-317, https://doi.org/10.1038/86684 (2001). 
7. Shi, C., Wu, J. B. \& Pan, D. Review on near-infrared heptamethine cyanine dyes as theranostic agents for tumor imaging, targeting, and photodynamic therapy. J. Biomed. Opt. 21, 50901, https://doi.org/10.1117/1.JBO.21.5.050901 (2016).

8. Sun, W., Guo, S., Hu, C., Fan, J. \& Peng, X. Recent Development of Chemosensors Based on Cyanine Platforms. Chem. Rev. 116, 7768-7817, https://doi.org/10.1021/acs.chemrev.6b00001 (2016).

9. Buxhofer-Ausch, V. et al. Tumor-specific expression of organic anion-transporting polypeptides: transporters as novel targets for cancer therapy. J. Drug. Deliv. 2013, 863539, https://doi.org/10.1155/2013/863539 (2013).

10. Liu, T. \& Li, Q. Organic anion-transporting polypeptides: a novel approach for cancer therapy. J. Drug. Target. 22, 14-22, https://doi. org/10.3109/1061186X.2013.832767 (2014).

11. Tan, X. et al. A NIR heptamethine dye with intrinsic cancer targeting, imaging and photosensitizing properties. Biomater. 33, 2230-2239, https://doi.org/10.1016/j.biomaterials.2011.11.081 (2012).

12. Thakkar, N., Lockhart, A. C. \& Lee, W. Role of Organic Anion-Transporting Polypeptides (OATPs) in Cancer Therapy. AAPS J. 17, 535-545, https://doi.org/10.1208/s12248-015-9740-x (2015).

13. Usama, S. M., Lin, C. M. \& Burgess, K. On the Mechanisms of Uptake of Tumor-Seeking Cyanine Dyes. Bioconjugate Chem. 29, 3886-3895, https://doi.org/10.1021/acs.bioconjchem.8b00708 (2018).

14. Feng, L. Z., Dong, Z. L., Tao, D. L., Zhang, Y. C. \& Liu, Z. The acidic tumor microenvironment: a target for smart cancer nanotheranostics. Natl Sci. Rev. 5, 269-286, https://doi.org/10.1093/nsr/nwx062 (2018).

15. Xue, F. et al. A smart drug: a pH-responsive photothermal ablation agent for Golgi apparatus activated cancer therapy. Chem. Commun. 53, 6424-6427, https://doi.org/10.1039/c7cc03168h (2017).

16. Zhang, J. et al. Selective imaging and cancer cell death via $\mathrm{pH}$ switchable near-infrared fluorescence and photothermal effects. Chem. Sci. 7, 5995-6005, https://doi.org/10.1039/c6sc00221h (2016).

17. Meng, X. et al. Dual-Responsive Molecular Probe for Tumor Targeted Imaging and Photodynamic Therapy. Theranostics 7, 1781-1794, https://doi.org/10.7150/thno.18437 (2017)

18. Atchison, J. et al. Iodinated cyanine dyes: a new class of sensitisers for use in NIR activated photodynamic therapy (PDT). Chem. Commun. 53, 2009-2012, https://doi.org/10.1039/c6cc09624g (2017).

19. Song, F. L. et al. Tuning the photoinduced electron transfer in near-infrared heptamethine cyanine dyes. Tetrahedron Lett. 46, 4817-4820, https://doi.org/10.1016/j.tetlet.2005.04.089 (2005)

20. Myochin, T. et al. Rational design of ratiometric near-infrared fluorescent $\mathrm{pH}$ probes with various $\mathrm{pKa}$ values, based on aminocyanine. J. Am. Chem. Soc. 133, 3401-3409, https://doi.org/10.1021/ja1063058 (2011).

21. Khalili, F., Henni, A. \& East, A. L. L. pKa Values of Some Piperazines at (298, 303, 313, and 323) K. J. Chem. Eng. Data 54, 2914-2917, https://doi.org/10.1021/je900005c (2009).

22. Suwannakham, P., Chaiwongwattana, S. \& Sagarik, K. Mechanisms of photoexcitation and photoionization in small water clusters. Rsc Adv. 8, 36731-36744, https://doi.org/10.1039/c8ra06095a (2018).

23. Sandell, J. L. \& Zhu, T. C. A review of in-vivo optical properties of human tissues and its impact on PDT. J. Biophotonics 4, 773-787, https://doi.org/10.1002/jbio.201100062 (2011)

24. Smith, A. M., Mancini, M. C. \& Nie, S. Bioimaging: second window for in vivo imaging. Nat. Nanotechnol. 4, 710-711, https://doi. org/10.1038/nnano.2009.326 (2009).

25. Lin, J. \& Alexander-Katz, A. Cell Membranes Open “Doors" for Cationic Nanoparticles/Biomolecules: Insights into Uptake Kinetics. ACS Nano 7, 10799-10808, https://doi.org/10.1021/nn4040553 (2013).

26. Pewklang, T., Chansaenpak, K., Lai, R. Y., Noisa, P. \& Kamkaew, A. Aza-BODIPY probe for selective visualization of cyclooxygenase-2 in cancer cells. Rsc Adv. 9, 13372-13377, https://doi.org/10.1039/c9ra01948k (2019).

\section{Acknowledgements}

This work was financially supported by Thailand Research Fund (TRF) under grant no. RTA6180007, the Thailand Research Fund and the Office of the Higher Education Commission (TRF-OHEC) under grant no. MRG6180030, and Thailand Graduate Institute of Science and Technology (TGIST) under grant no. SCA-CO-2562-9812-TH.

\section{Author contributions}

S.S. conceived the cell experiments and spectroscopic data, N.K. synthesized the compounds, K.C. conducted the photophysical properties, K. Si., P.P. and K. Sa. conducted the computational calculation, P.N., R.-Y.L. and A.K. analyzed the results, A.K. wrote the main manuscript text. All authors reviewed the manuscript.

\section{Competing interests}

The authors declare no competing interests.

\section{Additional information}

Supplementary information is available for this paper at https://doi.org/10.1038/s41598-020-58239-5.

Correspondence and requests for materials should be addressed to A.K.

Reprints and permissions information is available at www.nature.com/reprints.

Publisher's note Springer Nature remains neutral with regard to jurisdictional claims in published maps and institutional affiliations.

(c) (i) Open Access This article is licensed under a Creative Commons Attribution 4.0 International

License, which permits use, sharing, adaptation, distribution and reproduction in any medium or format, as long as you give appropriate credit to the original author(s) and the source, provide a link to the Creative Commons license, and indicate if changes were made. The images or other third party material in this article are included in the article's Creative Commons license, unless indicated otherwise in a credit line to the material. If material is not included in the article's Creative Commons license and your intended use is not permitted by statutory regulation or exceeds the permitted use, you will need to obtain permission directly from the copyright holder. To view a copy of this license, visit http://creativecommons.org/licenses/by/4.0/.

(C) The Author(s) 2020 